\title{
Muzyka jako nośnik "niewyrażalnego" w filmie Podwójne życie Weroniki Krzysztofa Kieślowskiego
}

\begin{abstract}
Al-Araj Anna, Muzyka jako nośnik "niewyrażalnego" w filmie "Podwójne życie Weroniki" Krzysztofa Kieślowskiego [Music as a transmission of "inexpressibility" in The Double Life of Véronique by Krzysztof Kieslowski] „Przestrzenie Teorii” 24, Poznań 2015, Adam Mickiewicz University Press, pp. 261-274. ISBN 978-83-232-2982-7. ISSN 1644-6763. DOI 10.14746/ pt.2015.24.14.

In this article I try to interpret the music aspect of Krzysztof Kieslowski's famous movie The Double Life of Véronique (1991, music: Z. Preisner). The director, whose works are full of allusions to music and generally to art, always paid special attention to the sound of his movies. The Double Life of Véronique, though not the last "fruit" of the cooperation between Kieslowski and Zbigniew Preisner, is the best illustration of this fact. The musical elements permeate almost all aspects of this work, from the plot to the structure of the movie (the use of the leitmotif technique), and correspond closely to the action. The key importance of music is illustrated by a description of what I consider to be the film's three most significant scenes: two from the "Polish" and one from the "French" part of this work.
\end{abstract}

\section{W stronę filmowej fikcji}

Dojrzałe dzieła Krzysztofa Kieślowskiego (1941-1996) - jednego z najbardziej rozpoznawalnych na arenie międzynarodowej polskich reżyserów, uznawanego za czołowego przedstawiciela kina moralnego niepokoju - w równym lub nawet w większym stopniu niż jego wcześniejsze dokonania potwierdzają tezę o przełomowości i innowacyjności tego dorobku filmowego ${ }^{1}$. W latach 80 . dążenia artysty uległy zasadniczemu

${ }^{1}$ Nie podważając przekonania o całkowitym nowatorstwie Kieślowskiego w dziedzinie reżyserii, Kaisa Hiltunen wskazuje na zauważalne w jego filmach wpływy stylistyk wypracowanych przez innych twórców, takich jak Ingmar Bergman, Michelangelo Antonioni, Andriej Tarkowski czy Éric Rohmer. W odniesieniu do Podwójnego życia Weroniki oraz Trzech kolorów autorka używa terminu „kino paneuropejskie”, ilustrując tym samym uniwersalność późnych dzieł Kieślowskiego (zob. K. Hiltunen, Images of Time, Thought and Emotions. Narration and the Spectator's Experience in Krzysztof Kieślowski's Late Fiction Films, Jyväskylä 2005, s. 180). Z drugiej jednak strony w wypowiedziach samego reżysera pobrzmiewa ton zwątpienia zarówno we własne, jak i „młodego pokolenia” twórców możliwości: „Milczenie Bergmana jest równie dojmujące jak nieobecność Felliniego, Buñuela i Tarkowskiego, piękne, ale nie porywające filmy Kurosawy i nieudane filmy Wajdy. Trzeba jasno powiedzieć, że my, młodsi o pokolenie lub dwa, nie potrafiliśmy 
przewartościowaniu - zwątpienie w możliwość uchwycenia i oddania za pomocą kamery tzw. prawdy obiektywnej, jak również względy etyczne wpłynęły na rezygnację Kieślowskiego $\mathrm{z}$ tworzenia filmów dokumentalnych i coraz większe zainteresowanie reżysera gatunkiem filmu fabularnego ${ }^{2}$. W kolejnych dziełach twórca koncentrował się przede wszystkim na charakterystyce wewnętrznego świata bohaterów - ich emocjach, wspomnieniach, snach i przeczuciach ${ }^{3}$. Mimo to przyznawał, iż rzetelny opis tych podświadomych często stanów jest niemożliwy do wykonania:

Celem jest dotarcie do tego, co istnieje wewnątrz człowieka, ale nie ma właściwej metody opisującej te zjawiska. Możesz się do nich nieco zbliżyć, jednak nigdy w pełni ich nie ujmiesz. [...] Kino nie ma narzędzi do zobrazowania tych stanów ${ }^{4}$.

Ta tematyczna i stylistyczna zmiana, której świadectwem są filmy powstałe po 1980 roku, wpłynęła na sposób opowiadania przez Kieślowskiego historii (czy raczej idei), zogniskowanych teraz wokół zindywidualizowanych bohaterów, a nie reprezentantów danych grup społecznych ${ }^{5}$.

ich zastąpiç" (zob. K. Kieślowski, Milczenie Bergmana, [w:] Magia kina, red. J. Wróblewski, Warszawa 1995, s. 53).

2 Po 1980 roku powstał tylko jeden film dokumentalny Kieślowskiego, zatytułowany Siedem dni w tygodniu (1988). Tadeusz Lubelski proponuje inne wytłumaczenie owej zaskakującej konwersji stylistycznej u reżysera, zwracając uwagę, że to właśnie artystyczne zniekształcenie pozwala w sposób bardziej adekwatny oddać rzeczywistość: „Kieślowski wyszedł od radykalnego mimetyzmu, z upływem lat jednak, przyglądając się rzeczywistości, coraz bardziej się przekonywał, że aby wiernie przedstawić świat, artysta musi go zniekształcać" (zob. tenże, Być artysta. Zobowiazania wobec sztuki w filmach Krzysztofa Kieślowskiego, [w:] Kino Kieślowskiego, kino po Kieślowskim, red. H. Wachnowska, Warszawa 2006, s. 52).

${ }^{3}$ Kieślowski porównywał swoją pracę do analizy fizycznej: „Fizycy szukają związków między mikroskopijnymi elementami, próbując wyjaśnić życiowe tajemnice. Prawdopodobnie ja robię to samo w swoich filmach" (zob. S. Mensonge, Three Colours: Blue, White and Red. Krzysztof Kieślowski and Friends, „Cinema Papers” 1994, nr 99, s. 28). Wszystkie cytaty z publikacji anglojęzycznych przytaczam we własnym tłumaczeniu. Wyróżnienia, jeżeli nie podano inaczej, pochodzą ode mnie.

${ }^{4}$ Kieślowski on Kieślowski, red. D. Stok, Helsinki 1993, s. 114. W innym miejscu reżyser ujmował ten problem w następujący sposób: „Ta historia traktuje o rzeczach, których nie można nazwać. Jeśli to zrobisz, zaczną wydawać się one trywialne i głupie” (zob. J. Romney, The Double Life of Véronique: Through the Looking Glass, http://www.crite rion.com/current/posts/457-the-double-life-of-veronique-through-the looking-glass, dostęp: 19.10.2013).

${ }^{5}$ Mimo licznych zmian dostrzegalnych w postawie twórczej Kieślowskiego po 1980 roku zasadne wydaje się rozpatrywanie jego dorobku w kategoriach ewolucji, na co wskazuje Hiltunen: „[Twórczość Kieślowskiego] składa się na wyraźne stylistyczne i tematyczne continuum, przebiegające od wczesnych filmów dokumentalnych i zwieńczone późnymi dziełami fabularnymi. Niemożliwe jest zatem wyznaczenie ścisłej granicy między wczesną i późną fazą [jego artystycznych osiągnięćc]". Zob. K. Hiltunen, dz. cyt., s. 9. 
Cechę tę można łączyć z deklarowanym przez reżysera we wczesnych latach 90 . brakiem zainteresowania kwestiami politycznymi ${ }^{6}$. W przekonaniu Kaisy Hiltunen w dojrzałych dziełach Kieślowskiego pojawiają się pewne aluzje do sytuacji społecznej (zmiany ustroju politycznego w Podwójnym życiu Weroniki czy zjednoczenia Europy w Trzech kolorach: Niebieskim), nie mają one jednak tak doniosłego znaczenia, jak w filmach reżysera z lat 70 . i początku lat 80.7 .

Przewodnim tematem późnych dzieł artysty jest niepoddająca się racjonalnemu wytłumaczeniu łączność duchowa odnoszona zarówno do wymiaru ludzkiego, jak i szeroko pojętej transcendencji ${ }^{8}$. Inny ważny problem stanowi swoistego rodzaju „alternatywnośc” życiowych dróg,

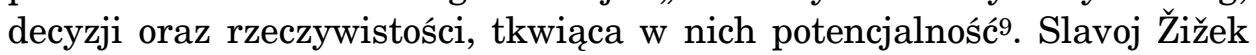
komentuje to w następujący sposób:

Obsesja Krzysztofa Kieślowskiego dotycząca roli przypadku i paralelnych, alternatywnych historii może być postrzegana jako dążność do wyrażenia tego nowe-

${ }^{6}$ Co znaczące, główna bohaterka filmu Podwójne życie Weroniki nie zważa, jak się zdaje, na rozgrywającą się na jej oczach demonstrację, idąc w przeciwnym kierunku niż strajkujący tłum. Weronika żyje niejako we własnym świecie i nie uświadamia sobie zmian czy przewrotów społecznych, które zachodzą wokół niej.

${ }^{7}$ K. Hiltunen, dz. cyt., s. 15-16. Margarete Wach interpretuje Podwójne życie Weroniki jako alegorię relacji między szeroko pojętym Wschodem (Polska) a Zachodem (Francja). Biorąc jednak pod uwagę zdecydowane oświadczenia reżysera („[...] to film o emocjach i niczym więcej”), takie rozumienie dzieła wydaje mi się nieuprawnione. Zob. Kieślowski on Kieślowski..., s. 218.

8 Obie główne bohaterki Podwójnego życia Weroniki czują, że „nie są same na świecie”. Warto wspomnieć, że w nowszych badaniach nad spuścizną Kieślowskiego i Preisnera analizuje się znamienne dla stylu twórców cechy, tj. hiperestetyzm i duchową egzaltację (a także eskapizm, pojęty jako narzucanie na rzeczywistość konwencji całkowicie nierealnej) w kontekście teorii kiczu. Por. A. Morstin-Popławska, Historia pewnego złudzenia. Teorie kiczu i „Podwójne życie Weroniki”, „Kwartalnik Filmowy” 2009, nr 66; B. Pawłowska-Jądrzyk, Sztuka metafizyczna czy kicz uwznioślony? (Stowo o „Podwójnym życiu Weroniki”), [w:] tejże, Uczta pod Wiszqca Skała. Metafizyczność i nieokreśloność w sztuce (nie tylko) literackiej, Warszawa 2011, s. 113-119; A. Chłopecki, Preisner, czyli apologia kiczu, „Tygodnik Powszechny” 1998, nr 44, s. 9. Interesujące wydają się ponadto uwagi Janusza Gazdy, obnażające wypracowaną przez Kieślowskiego sztukę manipulacji widzem i jego emocjami: „[materię swych filmów reżyser] inkrustuje elementami metafizycznymi. Metafizyka więc, jeśli się pojawia, nie przenika w sposób organiczny całego utworu, nie wypływa w sposób naturalny z takiego, a nie innego rozumienia świata przez artystę, lecz jest przez niego dopisywana, dodawana jako ozdobnik. Szczegóły, które ją mają sugerować, można by więc nazwać gadżetami metafizycznymi”. Zob. J. Gazda, Zimny kolor wolności, „Kwartalnik Filmowy” 1993/1994, nr 4, s. 90.

9 Slavoj Žižek używa w tym kontekście określeń „paralelne wszechświaty” [parallel universes] czy „scenariusze alternatywnych możliwych światów” [alternative possible worlds scenarios]. Zob. tegoż, The Double Life of Véronique: The Forced Choice of Freedom, $<$ http://www.criterion.com/current/posts/1733-the-double-life-of-veronique-the-forced-choi ce-of-freedom>, dostęp: 19.10.2013. 
go życiowego doświadczenia w całej jego ambiwalencji i to w sposób, który pozwala łączyć jego twórczość z dorobkiem najlepszych postmodernistycznych reżyserów ostatniej albo dwóch ostatnich dekad ${ }^{10}$.

Jedną z najciekawszych realizacji wymienionych wyżej wątków tematycznych obecnych w późnej twórczości Kieślowskiego jest jego pierwszy film powstały poza granicami Polski - Podwójne życie Weroniki (1991), w którym koegzystują one ze sobą na przestrzeni całego dzieła. Dość popularna i oczywista interpretacja, akcentująca paralelność losów Weroniki i Véronique, pozwala traktować perypetie tej ostatniej w kategoriach „drugiej szansy” czy też „alternatywnej ścieżki życiowej” (Véronique, kierując się wyłącznie intuicją, unika błędów popełnionych wcześniej przez Weronikę i decyduje się na rezygnację ze śpiewania11), co zresztą sugeruje tytuł tego „metafizycznego thrillera”12, eksponujaccy jedynie polską wersję imienia bohaterki13.

10 Tamże.

11 Wydaje się, że ten epizod można interpretować jako echo rozpowszechnionego w kulturze zachodniej motywu sztuki doprowadzającej twórcę (wykonawcę) do samounicestwienia. W tym rozumieniu każdy akt twórczy jest „życiopisaniem”, czyli - de facto „powolnym umieraniem”. Marek Hendrykowski w studium Visconti w Wenecji („Przestrzenie Teorii" 2012, nr 18, s. 155-172) interpretuje obecny w noweli Manna Śmierć w Wenecji i filmie Viscontiego motyw Erosa-Thanatosa w kontekście filozofii europejskiego modernizmu, co można zapewne odnieść także do dzieła Kieślowskiego. Inną ciekawą interpretację tego tropu w filmie Podwójne życie Weroniki zaproponował Paul Coates, przypominając przekonanie (podzielane m.in. przez XIX-wiecznych twórców opowieści grozy spod znaku E.T.A. Hoffmanna), zgodnie z którym ujrzenie własnej „połówki” jest zwiastunem rychłej śmierci. Véronique nie zauważyła obserwującej jej na Starym Rynku w Krakowie Weroniki i ten prosty fakt mógł uchronić ją od śmierci. W innym jednak miejscu badacz nie przecenia tego elementu akcji, stwierdzając: „Jeśli zetknięcie Weroniki z tą drugą sobą samą może sygnalizować śmierć, to jest to jednak tylko jej zapowiedź, nic więcej jak znak wymagający odczytania; prawdziwa śmierć - i to, co naprawdę trudne do zrozumienia pojawiają się dopiero później, być może w wyniku niemożności odczytania znaku, przeciążenia nieskończonymi pytaniami systemu nadawania znaczeń i doprowadzenia do zwarcia" (zob. P. Coates, The Story of the Lost Reflection. The Alienation of the Image in Western and Polish Cinema, London 1985, s. 11-13; tegoż, „Podwójne życie Weroniki”: podwajanie, fantazja i niewidzialna rama, [w:] Kino Kieślowskiego, kino po Kieślowskim..., s. 147-157). Z kolei Slavoj Žižek odnosi wybór, przed którym postawiona zostaje główna bohaterka, do biografii samego reżysera, który - świadom swoich problemów z sercem zdecydował się kontynuować działalność, być może przypłacając tę decyzję życiem. Taka interpretacja współbrzmi, jak się zdaje, z punktem widzenia twórcy, podkreślającego, iż nie można opowiedzieć świata inaczej, jak tylko przez siebie samego. Zob. S. Žižek, The Fright of Real Tears: Krzysztof Kieślowski between Theory and Post-Theory, London 2001, s. 137 .

12 W. Donner, Die eine singt, die andere nicht, „Tip” 1991, nr 22, s. 59.

13 Tytuł obrazu odsyła ponadto do problemu niejednoznaczności tkwiącej w kobiecości. Zdaniem reżysera jest to klasyczny film o kobiecie, ponieważ - zgodnie z jego opinią - to 


\section{Idiom Preisnera}

Kieślowski współpracował $\mathrm{z}$ wieloma osobami na różnych etapach powstawania filmów. Jednym z jego stałych pomocników był Krzysztof Piesiewicz, który przyczynił się do powstania scenariuszy siedemnastu obrazów twórcy. Bliskie kontakty utrzymywał Kieślowski także ze Zbigniewem Preisnerem - znanym kompozytorem muzyki filmowej. Międzynarodowy rozgłos i uznanie zapewniły artyście zwłaszcza ścieżki dźwiękowe do cyklu Dekalog, oraz filmów Podwójne życie Weroniki i Trzy kolory. Iwona Sowińska wspomina o dwóch zasadniczych „typach” proponowanego przez kompozytora muzycznego towarzyszenia w późnych filmach Kieślowskiego:

Pierwszy polegał na komponowaniu muzyki skromnej: pastelowej, ściszonej, przeznaczonej często na solowy instrument (głównie fortepian), o ażurowej strukturze (krótkie, jakby naszkicowane tylko motywy). [...] Drugi typ był przeciwieństwem pierwszego. To muzyka jaskrawa i mocna, przejawiająca nieposkromnioną skłonność do dominacji; operująca potężnym aparatem wykonawczym (solowym głosem, zwykle wspieranym przez chór i orkiestrę), kontrastami dynamiki, długimi odcinkami czasu - bo jej skonsumowanie wymaga przecież $\operatorname{czasu}^{14}$.

Charakterystyczne dla idiomu twórczego Preisnera dowartościowanie elementu melodycznego i tradycyjnej harmoniki funkcyjnej zbliża tę estetykę do postromantycznej ${ }^{15}$. Ważnym czynnikiem zapewniającym tej muzyce unikatowość jest także predylekcja do wykorzystania efektu pogłosu, $\mathrm{z}$ jednej strony nadającego tym utworom relaksacyjny ton, z drugiej zaś budzącego skojarzenia z akustyką typową dla budowli sakralnych, co oczywiście pomaga $\mathrm{w}$ wykreowaniu mistycznej i tajemniczej atmosfery właściwej filmom Kieślowskiego. Wszystkie te czynniki składają się na przekaz o silnym nasyceniu emocjonalnym, korespondujący z kompozytorskim punktem widzenia:

kobiety bardziej odczuwają, mają większą wrażliwość i intuicję: „Kobiety żyją intuicją, rozumieją intuicją, są pełne intuicji”. Zob. J. Łużyńska, Dylematy etyczne reżysera, „Tygiel Kultury" 1996, nr 6-7, s. 116.

${ }^{14}$ I. Sowińska, Preisner: post scriptum, [w:] Kino Kieślowskiego, kino po Kieślowskim..., s. 309.

15 Zob. klasyfikację muzyki filmowej zaproponowaną przez Rogera Hickmana w książce Reel Music (New York 2006, s. 39). Warto dodać, że - mimo technicznej prostoty - muzyka Preisnera pretenduje do miana niezależnego medium, kreującego oryginalny przekaz daleki od ubogiego komentarza. Jak wspomina kompozytor w jednym z wywiadów: „Jeżeli muzyka opowiada o tym samym, co jest już widoczne na ekranie, nie ma sensu jej słuchać" (zob. Edoardo Ponti's interview with Zbigniew Preisner, <http://www.musicolog. com/preisner_interview.asp\#.UmJ2V_lSjSA>, dostęp: 19.10.2013). 
Uważam, że nie powinniśmy czuć się zakłopotani z powodu naszych uczuć. Te uczucia są jedyną ważną rzeczą, którą mamy. [...] Nie chcę ich się wstydzić, chociaż nie należę do „otwartych” osób [... ${ }^{16}$.

W wypowiedziach Preisnera pobrzmiewa jednocześnie niechęć wobec prób muzykologicznej systematyzacji jego dorobku, co najlepiej bodaj oddaje ukute przez niego określenie „muzyka do nieistniejącego filmu” ( $m u$ sic for non-existing movie):

Uważam, że rozgłos mojej twórczości zapewniła muzyka do filmów Kieślowskiego. Sytuuje się ona „na granicy”. Nie jest to muzyka klasyczna, ale jednocześnie trudno ją nazwać muzyką filmową w dosłownym znaczeniu tego słowa. Tworzę własne kompozycje, robię twórczą muzykę [I make creations, I make creative music]. Właśnie dlatego przyjąłem, że chciałbym tworzyć muzykę będącą „pomiędzy" [in-between $]^{17}$.

Podwójne życie Weroniki to jeden z najbardziej „muzycznych” filmów Kieślowskiego, temat muzyki jest bowiem ściśle wpleciony w losy bohaterek i decyduje o przebiegu akcji (Weronika to młoda adeptka wokalistyki, Véronique z kolei jest nauczycielką muzyki w szkole podstawowej18). Element brzmieniowy decyduje ponadto o koherencji i formalnej integralności tego obrazu, którą zapewnia wykorzystanie techniki motywów przewodnich. Leitmotif, zaczerpnięty z dzieła fikcyjnego holenderskiego kompozytora i alter ego Preisnera - Van den Budenmayera - jest najpierw wykonywany przez Weronikę, następnie zaś towarzyszy (w różnych wariantach) perypetiom związanym z Véronique, ustanawiając tym samym ścisłą łączność między losami obu bohaterek ${ }^{19}$.

Muzyka Preisnera, ze względu na swoją asemantyczność, uwypukla złożoność i ambiwalentny - zarówno w warstwie tematycznej, jak i montażowej - charakter filmu Kieślowskiego. Paradoksalnie jednak owa wieloznaczność dźwiękowego komentarza, o funkcji nie tylko estetycznej, ale też - by tak rzec - egzystencjalnej, decyduje o uniwersalności przekazu

16 Tamże.

17 Tamże. Tę muzyczną ambiwalencję można traktować jako refleks typowej dla warsztatu Kieślowskiego metody zacierania granic między tym, co wewnętrzne i zewnętrzne, realne i nierealne, widzialne i niewidzialne, między osobistym i zbiorowym doświadczeniem. Wszystkie te sposoby służą zobrazowaniu niejednoznaczności i złożoności świata.

18 Warto zwrócić uwagę, że niemalże wszyscy bohaterowie tego filmu związani są w mniejszym lub większym stopniu ze sztuką i - zależnie od swojego doświadczenia i wie$\mathrm{ku}$ - zajmują wobec niej rozmaite stanowiska. Ta konstatacja pozwala interpretować obraz w kategoriach „zobowiązań wobec sztuki”, jak proponuje Lubelski. Zob. tenże, dz. cyt., s. $37-52$.

19 Ten motyw po raz pierwszy pojawił się już w Dekalogu IX. Co interesujące, niektórzy badacze (np. Kaisa Hiltunen, Marek Haltof) wskazują na podobieństwo postaci Weroniki do młodej śpiewaczki cierpiącej na chorobę serca z IX części Dekalogu. 
dzieła. Nie dziwi zatem fakt, że zyskuje na znaczeniu w scenach, w których protagoniści nie są zdolni przełożyć na słowa swoich niezdefiniowanych emocji i stanów ${ }^{20}$. O nowej jakości, która powstaje z połączenia obrazu i dźwięku, Kieślowski wypowiadał się w następujący sposób:

Można opisać coś [...], co nie istnieje ani w samym obrazie, ani w samej muzyce. Połączenie tych dwóch poziomów sprawia, że pojawia się określone znaczenie i określona wartość, że coś, co determinuje konkretną atmosferę, nagle zaczyna istnieće ${ }^{21}$.

\section{Żywioły obrazu i muzyki}

\section{"Deszczowa" muzyka}

Muzyka otwierająca film i towarzysząca początkowej sekwencji przybiera formę prostej, idyllicznej pieśni chóralnej utrzymanej w trójdzielnym metrum (Tu viendras). Widzowie nie znają źródła dochodzących dźwięków, gdyż tworzą one akompaniament dla czołówki (jest to tzw. nondiegetic music ${ }^{22}$ ), nie mają jednak problemu ze zidentyfikowaniem pastoralnego charakteru naczelnego tematu utworu. Iście niebiańska atmosfera panująca w kompozycji multiplikowana jest przez wykorzystanie wysokiego rejestru głosów kobiecych (czy raczej dziewczęcych) oraz rytmiczne ostinato w partii chóru (jednorodny puls ósemkowy przenikający całą pieśń i stanowiący tło dla partii solowej). Występująca na początku utworu faktura monodyczna zostaje z czasem rozbudowana do dwugłosowej, który to zabieg prowadzi do wzbogacenia spektrum brzmieniowego kompozycji ${ }^{23}$.

W drugiej części sceny następuje zbliżenie kamery na główną bohaterkę - dysponującą najbardziej nośnym głosem, która wykonuje rustykalną w charakterze pieśń przy wtórze innych chórzystek. Śpiew Weroniki wraz z kolejnymi taktami utworu zyskuje na intensywności,

20 Hiltunen używa w odniesieniu do filmów Podwójne życie Weroniki i Trzy kolory określenia „wizualne symfonie” [visual symphonies]. Zob. taż, dz. cyt., s. 112.

${ }^{21}$ Kieślowski on Kieślowski..., s. 179.

${ }^{22}$ Więcej informacji dotyczących podziału na diegetic i nondiegetic music można znaleźć m.in. w publikacji autorstwa Claudii Gorbman Unheard melodies. Narrative Film Music (London 1987).

${ }^{23}$ Mówiąc o fakturze monodycznej, mam na myśli naczelny temat pieśni prowadzony przez głosy solowe unisono, który z czasem ulega „rozszczepieniu” na dwie odrębne linie melodyczne (sopranową i altową). Ostinatowe towarzyszenie utrzymane jest od samego początku w fakturze wielogłosowej, stanowi jednak przede wszystkim tło dla partii solowej. 
prowadząc w rezultacie do zdominowania - pod względem zarówno dynamicznym, jak i barwowym - pozostałych głosów i zyskując pierwszeństwo $\mathrm{w}$ finalnym momencie. Główna bohaterka, w przeciwieństwie do innych chórzystek, wykonuje pieśń do końca (stanowcza i przedłużająca się w czasie koda przypomina, jak się zdaje, o artystycznej determinacji Weroniki) i nie szuka schronienia przed deszczem ${ }^{24}$.

W kontekście powyższych rozważań muzykę towarzyszącą scenie otwierającej film można interpretować jako wyraz życiowej postawy Weroniki - jej optymizmu (doskonale oddanego przez jej skierowanie twarzy ku niebu), niefrasobliwości czy beztroskiego i pełnego temperamentu usposobienia ${ }^{25}$. Za takim rozumieniem przemawia także warstwa słowna pieśni, eksponująca stany ducha o zdecydowanie pozytywnym nacechowaniu: nadzieję na przybycie kogoś ważnego, wyrażoną w formie bezpośredniego zwrotu do adresata (Przyjdziesz w upalny, skwarny dzień; Pochylisz ku mnie miodny dzban; Tam staniesz piękna, wszystka, drżaca), zachwyt nad pięknem natury ( $W$ dolinę kwiatów, traw i słońca), wytrwałość w oczekiwaniu i oddanie (Pić będę z twoich dłoni; Tam czekać będę z pieniem pień). Zarówno warstwa słowna, jak i muzyczna utwierdzają w przekonaniu, że inicjalna pieśń chóru wpisuje się w topikę hymnu na cześć młodości.

\section{Łabędzi śpiew}

Centralną scenę w filmie Podwójne życie Weroniki stanowi ów zgubny dla głównej bohaterki koncert, kończący się jej śmiercią. Tego tragicznego wieczoru w sali filharmonii rozbrzmiewa dzieło Van den Budenmayera, będące źródłem pomysłów melodycznych wykorzystanych na przestrzeni całego obrazu ${ }^{26}$. Najważniejszą rolę odgrywa główny temat

24 Jak zauważa Romney: „Ta scena definiuje Weronikę jednocześnie jako istotę uduchowioną i kobietę podatną na ziemskie rozkosze" (tenże, dz. cyt.).

${ }^{25}$ Niewykluczone, że to właśnie owa spontaniczna natura, pewnego rodzaju nonszalancja życiowa Weroniki przyczyniły się do jej przegranej. Postać Véronique została bowiem wyposażona w odmienne cechy charakteru, również kojarzone, co prawda, ze sferą zmysłowości, jednak bardziej oswojonej i odnoszącej się do wymiaru duchowego, a nie cielesnego.

26 Rzecz zastanawiająca, dlaczego Preisner zatytułował to dzieło Concerto in e minor, skoro w utworze nie został wykorzystany solowy instrument koncertujący. Jeżeli zaś weźmiemy pod uwagę obecność głosów wokalnych, bardziej adekwatnym określeniem gatunkowym byłaby symfonia wokalno-instrumentalna (ciesząca się zresztą dużym zainteresowaniem wśród kompozytorów romantycznych i neoromantycznych). Kolejny paradoks stanowi rzekomy czas powstania dzieła (XVIII w.), w żaden sposób nie korespondujący ze stylistyką, w której utrzymana jest kompozycja. Wydaje się więc, że wszystkie te zabiegi 
utworu, pojawiający się następnie w scenach eksponujących łączność duchową obu bohaterek. Zgodnie z opinią reżysera, to muzyka, a nie słowo (w utworze wykorzystano fragment II Pieśni z Raju Dantego), ma $\mathrm{w}$ tej scenie zasadnicze znaczenie ${ }^{27}$. Nie jest jednak zapewne dziełem przypadku, że do naczelnych problemów eksponowanych w owym wyimku z Boskiej Komedii należą kruchość ludzkiej egzystencji („O voi che siete in piccioletta barca"28) czy idea śmierci jako wiecznego powrotu, dopłynięcia do drugiego brzegu rzeki („Non vi mettete in pelago, ché forse, perdendo me, rimarreste smarriti”29).

Temat przewodni, zarówno kompozycji, jak i całego filmu, wprowadzony zostaje przez obój, którego brzmienie stanowi być może reminiscencję brzmienia fletu wykorzystanego $\mathrm{w}$ tematach przypisanych postaciom Weroniki i Véronique. Naczelny motyw pojawia się w dalszym przebiegu także w partii wokalnej. Muzyka utrzymana jest $\mathrm{w}$ stylistyce XIX-wiecznej, z typową dla niej dominacją elementu melodycznego, harmoniki funkcyjnej, przy wykorzystaniu obsady orkiestry symfonicznej. Zwraca ponadto uwagę wprowadzenie dźwięku dzwonów oraz tonacji $\mathrm{w}$ trybie molowym - oba elementy można uznać w tym kontekście za zwiastuny śmierci. Kolejny charakterystyczny zabieg wykorzystany $\mathrm{w}$ utworze to dialogiczna faktura, szczególnie słyszalna w interakcjach zachodzących między partią oboju i solistki (Weroniki) ${ }^{30}$. O monumentalnym charakterze tej muzyki $\mathrm{w}$ dużym stopniu decyduje połączenie brzmienia orkiestry symfonicznej o rozbudowanym składzie (dzwony, chór, soliści) z predylekcją do rozległego układu harmonicznego.

W trakcie występu Weronika zaczyna się chwiać, w związku z czym wyśpiewywane przez nią dźwięki tracą na klarowności i stają się intonacyjnie niepoprawne. Kamera symuluje zawroty, których doświadcza bohaterka, dzięki czemu oglądamy całe zajście niejako jej oczyma. Po chwili następuje upadek kobiety, któremu towarzyszy wirowy ruch kamery oraz charakterystyczne uderzenie (diegetic sound). Bezpośrednio po nim ukazany zostaje pogrzeb Weroniki (elipsa), w warstwie dźwiękowej ograniczony do słabego szumu upadającego piasku, i zabieg ten ponownie

zostały przez Preisnera wprowadzone celowo - z zamiarem obnażenia historycznej mistyfikacji, jaką się posłużono. Por. I. Sowińska, dz. cyt., s. 309-310.

27 Utrzymanie muzyki towarzyszącej słowom Dantego w konwencji operowej, wpływającej na mniejszą zrozumiałość czy wręcz komunikatywność tekstu, oraz wykorzystanie języka włoskiego w sposób naturalny utrudniają odbiór.

28 Dante Alighieri, La Divina Commedia, Bari 1933, s. 316.

29 Tamże, s. 316.

30 Mam na myśli zarówno imitacje, jak i kontrapunktyczne dialogi, w których jedna partia przeciwstawia się drugiej, przypominając o zmaganiach Weroniki z jej alter ego albo śmiercią. 
daje widzowi możliwość przyjęcia iluzorycznej perspektywy głównej bohaterki ${ }^{31}$.

Ta scena ściśle łączy się ze sceną miłosną z udziałem Véronique i jej partnera. To płynne przejście jest nie tylko próbą wskazania na procesualny charakter zdarzeń (metafora „przekazania ducha”, następstwa życia i śmierci), ale nawiązuje także bezpośrednio do rozpowszechnionej $\mathrm{w}$ kulturze zachodniej topiki miłosno-funeralnej. W myśl tego przekonania każdy akt ofiarowania - czy to cielesnego, czy to duchowego - doprowadza do częściowej destrukcji podmiotu, zaś ekstaza miłosna stanowi rodzaj „małej śmierci” ${ }^{32}$. Ów rytuał przejścia, z którym mamy do czynienia na przestrzeni tych dwóch scen, podkreślany jest $\mathrm{w}$ warstwie wizualnej za pomocą charakterystycznego rozmycia obrazu (wykorzystanie przezroczystych przedmiotów zniekształcających obraz) ${ }^{33}$. Strona dźwiękowa ogranicza się właściwie wyłącznie do miarowych oddechów kochanków - wszystkie inne odgłosy ulegają wyciszeniu - co sugeruje, że świat przedstawiony zostaje ponownie zawężony do perspektywy głównej bohaterki (metadiegetic sound). Wraz z zakończeniem aktu miłosnego obraz się normalizuje, zaś Véronique wyznaje, że odczuwa smutek. W tym samym momencie zostaje przypomniany leitmotif $\mathrm{z}$ dzieła Van den Budenmayera, odsyłający do „źródła” przygnębiającego nastroju (nondiegetic music).

\section{W miniaturowym świecie}

Oglądane przez Véronique i jej uczniów przedstawienie kukiełkowe w alegoryczny sposób nawiązuje do głównego tematu filmu. Jak się jednak zdaje, najważniejsza jest tutaj nie sama historia o śmierci i ponownych narodzinach baletnicy (zabieg „tekstu w tekście”), lecz rola, jaką w tej opowieści odgrywa „pociągający za sznurki” Alexandre. Ten „artysta

31 Marek Haltof porównuje tę scenę do analogicznej występującej w filmie Vampyr (1932) Carla Theodora Dreyera. Zob. tenże, The Double Life of Véronique: Doppelgängers and Puppeteers, [w:] tenże, The Cinema of Krzysztof Kieślowski. Variations on Destiny and Chance, London 2004, s. 114-122.

32 Takie ujęcie pozwala lepiej zrozumieć towarzyszący Véronique po przeżyciu miłosnej rozkoszy dojmujący smutek.

${ }^{33}$ Rozmaitego rodzaju odbijające i przezroczyste powierzchnie, przedmioty czy soczewki są centralnym motywem wizualnym tego filmu. Reżyser wprowadza je już w prologu (mała szklana kula), antycypując problematykę poruszaną w obrazie. Wykorzystanie tego typu elementów służy nie tylko „zwielokrotnieniu” filmowej przestrzeni, podkreśla także ambiwalentny charakter opisywanej historii i iluzyjność naszego poznania rzeczywistości. 
interdyscyplinarny"34 jawi się w świetle tej i kolejnych scen jako pośrednik między dwiema kobietami, wszechwiedzący zaklinacz rzeczywistości. Taka interpretacja postaci Alexandre'a - kreatora (ale też manipulatora) zdarzeń przedstawionych $\mathrm{w}$ obrazie i porte-parole reżysera - pozwala analizować to dzieło na poziomie metatekstowym, jako historię o tworzeniu i posłannictwie sztuki.

Przedstawionemu w pierwszej części sceny spektaklowi towarzyszy nieskomplikowany utwór fortepianowy o symetrycznej budowie (diegetic music). Jego sugestywność i „transowy” charakter multiplikowany jest przez wprowadzenie homofonicznej faktury (linia melodyczna i akompaniament w postaci basu Albertiego) oraz regularnej pulsacji rytmicznej (triole), zaburzanej czasem przez wykorzystanie tempa rubato. Elementy te pomagają $\mathrm{w}$ wykreowaniu znamiennej dla tej sceny subtelnej i tajemniczej aury. Procesowi fizycznego i duchowego „odradzania się" zmarłej baletnicy (aluzje do przepoczwarzania się motyla) towarzyszy znany temat z kompozycji Van den Budenmayera. W tym momencie spojrzenia Véronique i Alexandre'a spotykają się ${ }^{35}$, zaś muzyka - przerwana w tym samym miejscu, co podczas koncertu - staje się odzwierciedleniem myśli i emocji głównej bohaterki (metadiegetic music). Tadeusz Lubelski zwraca uwagę na zaakcentowanie przez Kieślowskiego w tej scenie „poznawczej” wartości sztuki, stwierdzając: „[...] w szczególnych okolicznościach, kiedy specjalne właściwości artysty zbiegają się ze specjalnym nastawieniem odbiorcy, utwór artystyczny może przeobrazić człowieka, dostarczyć mu klucza do jego prywatnej, intymnej tajemnicy”36.

\section{Pytania bez odpowiedzi}

Kieślowski zadaje w swoich filmach całą serię egzystencjalnych pytań w rodzaju: „Do jakiego stopnia możemy kontrolować własne życie?”, „Przed kim jesteśmy odpowiedzialni za podejmowane działania?” czy „Jak powinniśmy żyć?”. Reżyser nie udziela na nie odpowiedzi, ograniczając się jedynie do sugerowania ${ }^{37}$, strategia twórcy polega bowiem na unikaniu dyskursywnego wywodu, objaśnień explicite (wypowiedzi bohaterów

34 T. Lubelski, dz. cyt., s. 48.

35 Coates utrzymuje, że wzrok Véronique wędruje poprzez śmierć (czerń kojarzona z martwą Weroniką) ku życiu (wizerunek lalkarza będący substytutem obrazu Weroniki). Zob. tenże, dz. cyt., s. 153.

36 T. Lubelski, dz. cyt., s. 50.

37 Jako że Kieślowski unika prowadzenia bezpośredniego wywodu, wszystkie ewentualne sugestie i opinie zawierają się $\mathrm{w}$ sposobie organizacji i przedstawienia materiału filmowego. 
oddają jedynie wahanie i niepewność), i pozostawianiu ewentualnych konkluzji odbiorcy. Taka postawa wiąże się, jak sądzę, z przekonaniem o niepoznawalności i niewyrażalności istoty zjawisk, o których traktują późne dzieła Kieślowskiego.

W wielu obrazach reżysera $\mathrm{z}$ przełomu lat 80 . i 90 . oraz z lat 90 . to muzyka staje się substytutem słowa, pełni funkcję uniwersalnego języka wyrażającego odwieczne dylematy ludzkości. Pozwala ona na zniesienie socjokulturowych granic czy uprzedzeń i pomaga w interpretacji poszczególnych scen. $\mathrm{O}$ wadze tego elementu w filmach Kieślowskiego w ten sposób wypowiedziała się Maria Kornatowska:

Kieślowski posługuje się nią [muzyką - przyp. A.A.] z niezwykłym wyczuciem. Późne filmy tworzą specyficzną całość dźwiękowo-wizualną. Muzyka Zbigniewa Preisnera „wchodzi” w tkankę obrazu, łączy się z nim nieomal symbiotycznie, potęguje jego ekspresję, sugeruje podniosłość tonu, duchowe głębie i podskórne znaczenia. Buduje misterną siatkę skojarzeń. Manipuluje uczuciami odbiorców. Uszlachetnia prozę życia, nobilituje bohaterki i nas widzów. Przenosi w wyższe rejony bytu. Późne filmy wydawałyby się puste bez tej muzyki. Martwe e ${ }^{38}$.

Dowartościowanie warstwy dźwiękowej dzieła filmowego u Kieślowskiego przyczyniło się zapewne do niegasnącej popularności tych obrazów, które zmieniły i wciąż zmieniają stosunek wielu osób do rzeczywistości. O jednym z takich przypadków wspominał reżyser:

W Paryżu spotkałem 15-letnią dziewczynę, która przy pewnej okazji podeszła do mnie i wyznała, że oglądała Podwójne życie Weroniki. Oglądała ten film raz, dwa, trzy razy i chciała powiedzieć tylko jedną rzecz - że dzięki niemu zrozumiała, że dusza istnieje. [...] Było w tym [wyznaniu - przyp. A.A.] coś bardzo pięknego. Warto było zrobić Podwójne życie Weroniki choćby przez wzgląd na tę jedną dziewczynę 39 .

Nagromadzenie i intensyfikacja cech definiujących szeroko pojmowany nurt „kina metafizycznego” (eksponowanie bodźców estetycznych w tym muzyki, i silnych sygnałów emocjonalnych, mnożenie symbolicznych asocjacji i odwołań do sztuki wysokiej) w filmie Podwójne życie Weroniki skłoniły Gaylyna Studlara do następującej konkluzji: „Wygląda

${ }_{38}$ M. Kornatowska, Metafizyczne tajemnice Krzysztofa Kieślowskiego, [w:] Kino Kieślowskiego, kino po Kieślowskim..., s. 87. Co interesujące, autorka wysnuwa analogię między twórczością reżysera i dziełami literackimi Haruki Murakamiego, zwracając uwagę na podobieństwa w zakresie zabiegów formalnych stosowanych przez obu artystów, sposobów opowiadania, strategii narracyjnych, wątków tematycznych (obsesja śmierci) czy skomplikowanych relacji między postaciami. Kornatowska wskazuje ponadto na obecność licznych aluzji muzycznych w dziełach japońskiego pisarza (zob. też: J. Rubin, Haruki Murakami i muzyka słów, tłum. W. Górnaś, Warszawa 2008).

${ }^{39}$ Kieślowski on Kieślowski..., s. 244. 
to prawie jak rzeczywista parodia wszystkich ustanowionych stereotypów kina kontynentalnego kojarzonego z wcześniejszą generacją twórców, takich jak Ingmar Bergman czy Alain Resnais"40. W rzeczywistości ten przykład kina paneuropejskiego stanowi wyraz myślenia „późnego” Kieślowskiego, w którego twórczości muzyka pozostaje zasadniczym nośnikiem „niewyrażalnego”.

\section{LITERATURA}

Chłopecki A., Preisner, czyli apologia kiczu, „Tygodnik Powszechny” 1998, nr 44, s. 9. Coates P., „Podwójne życie Weroniki”: podwajanie, fantazja i niewidzialna rama, [w:] Kino Kieślowskiego, kino po Kieślowskim, red. H. Wachnowska, Warszawa 2006, s. $147-157$.

Coates P., The Story of the Lost Reflection. The Alienation of the Image in Western and Polish Cinema, London 1985.

Dante Alighieri, La Divina Commedia, Bari 1933.

Donner W., Die eine singt, die andere nicht, „Tip” 1991, nr 22.

Edoardo Ponti's interview with Zbigniew Preisner, <http://www.musicolog.com/prei sner_interview.asp\#.UmJ2V_ISjSA>.

Gazda J., Zimny kolor wolności, „Kwartalnik Filmowy” 1993/1994, nr 4.

Gorbman C., Unheard melodies. Narrative Film Music, London 1987.

Haltof M., The Double Life of Véronique: Doppelgängers and Puppeteers, [w:] tegoż, The Cinema of Krzysztof Kieślowski. Variations on Destiny and Chance, London 2004, s. 114-122.

Hendrykowski M., Visconti w Wenecji, „Przestrzenie Teorii” 2012, nr 18, s. 155-172.

Hickman R., Reel music, New York 2006.

Hiltunen K., Images of Time, Thought and Emotions. Narration and the Spectator's Experience in Krzysztof Kieślowski’s Late Fiction Films, Jyväskylä 2005.

Kieślowski K., Milczenie Bergmana, [w:] Magia kina, red. J. Wróblewski, Warszawa 1995.

Kieślowski on Kieślowski, red. D. Stok, Helsinki 1993.

Kornatowska M., Metafizyczne tajemnice Krzysztofa Kieślowskiego, [w:] Kino Kieślowskiego, kino po Kieślowskim, red. H. Wachnowska, Warszawa 2006.

Lubelski T., Być artystą. Zobowiazania wobec sztuki w filmach Krzysztofa Kieślowskiego, [w:] Kino Kieślowskiego, kino po Kieślowskim, red. H. Wachnowska, Warszawa 2006, s. 37-52.

Łużyńska J., Dylematy etyczne reżysera, „Tygiel Kultury” 1996, nr 6-7.

Mensonge S., Three Colours: Blue, White and Red. Krzysztof Kieślowski and Friends, „Cinema Papers” 1994, nr 99.

Morstin-Popławska A., Historia pewnego złudzenia. Teorie kiczu i „Podwójne życie Weroniki”, „Kwartalnik Filmowy” 2009, nr 66.

${ }^{40}$ G. Studlar, The Double Life of Véronique, [w:] Magill's Cinema Annual 1992:

A Survey of the Films of 1991, red. F.N. Magill, Salem 1992, s. 120. 
Pawłowska-Jądrzyk B., Sztuka metafizyczna czy kicz uwznioślony? (Słowo o „Podwójnym życiu Weroniki”), [w:] tejże, Uczta pod Wiszaca Skata. Metafizyczność i nieokreśloność w sztuce (nie tylko) literackiej, Warszawa 2011, s. 113-119.

Romney J., The Double Life of Véronique: Through the Looking Glass, <http://www. criterion.com/current/posts/457-the-double-life-of-veronique-through-the lookingglass $>$.

Rubin J., Haruki Murakami i muzyka słów, tłum. W. Górnaś, Warszawa 2008.

Sowińska I., Preisner: post scriptum, [w:] Kino Kieślowskiego, kino po Kieślowskim, red. H. Wachnowska, Warszawa 2006.

Studlar G., The Double Life of Véronique, [w:] Magill's Cinema Annual 1992: A Survey of the Films of 1991, red. F.N. Magill, Salem 1992.

Žižek S., The Double Life of Véronique: The Forced Choice of Freedom, <http://www. criterion.com/current/posts/1733-the-double-life-of-veronique-the-forced-choice-offreedom>.

Žižek S., The Fright of Real Tears: Krzysztof Kieślowski between Theory and PostTheory, London 2001. 